ISSN 1392-0340 (Print)

ISSN 2029-0551 (Online)

https://doi.org/10.15823/p.2021.144.2

\title{
The Interaction Between Understanding of Critical Thinking and Teaching/Learning of Critical Thinking Skills
}

Valdonė Indrašiené $\dot{1}^{1}$, Violeta Jegelevičiene் ${ }^{2}$, Odeta Merfeldaité ${ }^{3}$, Daiva Penkauskiené $\dot{ }^{4}$ Jolanta Pivoriené $\dot{5}^{5}$ Asta Railiene் $\dot{e}^{6}$, Justinas Sadauskas ${ }^{7}$, Natalija Valavičienè ${ }^{8}$

1 Mykolas Romeris University, Institute of Education Science and Social Work, Ateities g. 20, 08303 Vilnius, Lithuania, v.indrasiene@mruni.eu

2 Mykolas Romeris University, Institute of Education Science and Social Work, Ateities g. 20, 08303 Vilnius, Lithuania, violeta.suboc@mruni.eu

3 Mykolas Romeris University, Institute of Education Science and Social Work, Ateities g. 20, 08303 Vilnius, Lithuania, o.merfeldaite@mruni.eu

4 Mykolas Romeris University, Institute of Education Science and Social Work, Ateities g. 20, 08303 Vilnius, Lithuania, daiva.penkauskiene@mruni.eu

5 Mykolas Romeris University, Institute of Education Science and Social Work, Ateities g. 20, 08303 Vilnius, Lithuania, jolantapiv@mruni.eu

6 Mykolas Romeris University, Institute of Education Science and Social Work, Ateities g. 20, 08303 Vilnius, Lithuania, asta.railiene@mruni.eu

$7 \quad$ Mykolas Romeris University, Institute of Education Science and Social Work, Ateities g. 20, 08303 Vilnius, Lithuania, justas_sad@mruni.eu

8 Mykolas Romeris University, Institute of Education Science and Social Work, Ateities g. 20, 08303 Vilnius, Lithuania,natalijav@mruni.eu

Annotation. This article aims to present the interaction between understanding of critical thinking and teaching and learning of critical thinking skills in higher education in Lithuania. Representative quantitative research was implemented, and 152 teachers and 1512 students took part in the survey. Exploratory factor analysis revealed two factors - the rigidity and elasticity of the conception of critical thinking - that have an impact on teaching and learning of critical thinking skills.

Keywords: critical thinking, higher education, critical thinking skills, teaching, learning. 


\section{Introduction}

Critical thinking is at the heart of higher education (Wilson, 2016) and is an important goal in modern schooling. Its implementation provides students with the competencies needed to develop a personality (Veliz \& Veliz-Campos, 2019) and to solve problems in a rapidly changing and uncertain world (Facione \& Facione, 1996; Ku, 2009; Dwyer et al., 2012; Ghanizadeh, 2017). The demand for critical thinking is growing along with challenges and complex problems in a global, competitive environment (Smith \& Stitts, 2013) that have not existed before.

Critical thinking is an ambiguous concept that is defined differently by different researchers and theoretical schools. The classical definition of critical thinking states that it is the totality of a person's cognitive skills (to interpret and analyse, to explain and evaluate, and to draw conclusions and make the corrections stemming from them) and dispositions (open-mindedness and inquisitiveness, analyticity and systematicity, trust in soundness and the pursuit of truth) (Facione, 1990). The importance of skills is also emphasised by Siegel (1988), who argues that critical thinking is the ability to be guided by substantiated arguments in various contexts in pursuit of substantiated and rational decisions, and by Beyer (1987), who defines critical thinking as the ability to argumentatively question unsubstantiated assumptions and reasoning in pursuit of truth and rightness. By including the aspects of truth and rightness, the latter definition also gives critical thinking a social meaning that is further emphasised by Barnett (1997), who argues that critical thinking is the ability to reason, reflect and act critically for the good of oneself, others and society. Other authors associate critical thinking more with the process of personal development, emphasising that it is the improvement of a person's thinking by changing habitual thinking patterns (Halpern, 1998), or a strong human-development thinking based on firm knowledge, cognitive skills, and honest, moral behaviour in all life situations (Paul \& Elder, 2001). Ennis (1987) singles out reflexivity and argues that critical thinking is reflexive thinking when making a substantiated decision about what and what not to believe.

The first attempt to systematise critical thinking skills was presented in the Delphi expert consensus, which lists the core critical thinking skills such as analysis, evaluation, explanation, inference, interpretation, and self-regulation (Facione, 1990). Ennis (1987) and Beyer (1987) add the ability to evaluate assumptions, causes, and opinions to the skill of evaluation. Ennis (1987) expands the definition of explanation and adds sub-skills such as the ability to formulate questions, ask and answer clarifying/challenging questions, determine and/or formulate criteria for decision making, and analyse arguments. The inference is given as having sub-skills such as deductive and inductive inference (Beyer, 1987), the exploration of reasonableness, and anticipation of alternatives (Ennis, 1987). Other researchers attribute decision-making (Ennis, 1987; Halpern, 1998; Beyer, 1987), argumentation and reasoning (Halpern, 1998; Beyer, 1987) to critical thinking skills. 
Decision-making (Ennis, 1987; Halpern, 1998; Beyer, 1987) is explained as the ability to evaluate source reliability (Ennis, 1987; Halpern, 1998), make decisions, and defend them by integrating all dispositions and skills (Ennis, 1987), follow observational process rules (Ennis, 1987; Beyer, 1987), and maintain consistency in making decisions (Ennis, 1987; Beyer, 1987). The reasoning is defined as scientific thinking to avoid pseudoscience (Halpern, 1998; Barnett, 1997).

Teaching and learning critical thinking skills is a complex process which among other important aspects is shaped by teacher and students understanding of critical thinking. The importance of developing critical thinking skills and the challenges faced by teachers in the study process have been drawing the attention of researchers around the world (Evens et al., 2014; Gillespie \& McBain, 2014). Researchers argue that critical thinking can be learned, encouraged, and developed (Niu et al., 2013; Abrami et al., 2015, Veliz \& Veliz-Campos, 2019; Puig et al., 2019). To achieve this, the development of critical thinking must be included in every study discipline (Penningroth et al., 2007), thereby justifying the objectives of higher education in terms of critical thinking (Ghanizadeh, 2017).

According to Edwards (2017), the inclusion of specific critical thinking skills in course content is an effective way to promote critical thinking among students. Also, incorporating critical thinking into the teaching may improve other skills, such as language skills (Toshpulatova \& Kinjemuratova, 2020), or have general positive impact on students' academic achievements (Tiruneh et al., 2018).

However, researchers (Arth et al., 2019) note that students likely will not learn better critical thinking skills alone, also, student-centered learning in higher education requires the instructor to guide students to use the course concepts (Wright, 2011), therefore, systematically designed learning activities are crucial to acquire critical thinking. Integration of critical thinking activities into coursework or lectures, creating opportunities for appropriate and effective questioning (Fitriani et al., 2021), referring to content from related disciplines (Norris, 2016) can stimulate students to think at a higher cognitive level. Moreover, by developing critical thinking, teachers also contribute to the development of other soft skills to be applicable at the workplace (Tang, 2019).

In the context of higher education, critical thinking is referred to as conscious and purposeful teaching and learning activity. Studies (Kozikoglu, 2019; Özelçi \& Çaliskan, 2019) show, that teacher's thinking and learning have great importance in stimulating students' thinking processes. On the other hand, confidence in own teaching practices, in turn, can create an efficient learning environment (Pearman et al., 2021). Hence, the role of a teacher in contributing to strengthening students' critical thinking competencies is very important.

Critical thinking is one of the most desirable intended learning outcomes in higher education and interest in developing critical thinking is growing among teachers, but some studies show that this goal is not being realised successfully. For example, Tsui (2008) argues that most teachers do not have sufficient pedagogical training and lack the 
knowledge necessary to develop critical thinking (Zhang et al., 2020), and therefore they teach ineffectively (Crenshaw et al., 2011; Edwards, 2017). The interest to incorporate the teaching of critical thinking skills is increasing, but an overall lack of consistency in the implementation process is noted (Veliz \& Veliz-Campos, 2019).

This illustrates that the teacher's understanding of critical thinking is central when interacting with students, and this influences the entire teaching process, creates a learning environment for students, and influences their motivation and achievements (Dehghayedi \& Bagheri, 2018). The teacher's understanding reflects their perceptions and beliefs, and this determines the choice of appropriate behaviour or strategies in the teaching process (Zhang et al., 2020; Torff, 2005).

The development of critical thinking skills should be seen as a two-way process, in which interaction between teacher and student becomes particularly important. Both the teacher and the student are active and significant participants in shaping students' critical thinking. The interfaces of the construction of how teachers think and what they believe and know are explained by the teachers' interaction with students (Borg, 2003). Encouraging students to be independent thinkers Cohen (1993) argues that critical thinking is not just a series of thinking skills, but also the character traits that enable individuals to examine their own thinking. The teacher's understanding of critical thinking interacts with their type of work they do with students. It is important to emphasise this aspect when researching the teacher's role in the development of critical thinking and power to make a difference.

This article aims to present the interaction between understandings of critical thinking and teaching and learning of critical thinking skills in higher education in Lithuania. It presupposes two objectives: to investigate how critical thinking is understood by teachers and students, and to examine how teachers' understanding about critical thinking whether it is an acquired skill or whether it is an innate characteristic - are related to the critical thinking development.

\section{Materials and Methods}

Participants and procedures. The representative online survey involved 152 teachers and 1512 students of the Lithuanian higher education institutions. A multistage probability sampling method was used (detail in Table 1). Participation in the study was voluntary. The respondents were assured that the data submitted would remain anonymous and would only be made public in an aggregated form. 
Table 1

Social and Demographic Characteristics of the Participants

\begin{tabular}{|c|c|c|}
\hline & Teachers & Students \\
\hline Number of research participants & 152 & 1512 \\
\hline Age (average) & 48.9 & 23.8 \\
\hline \multicolumn{3}{|c|}{ Gender } \\
\hline Women & $64.0 \%$ & $60.3 \%$ \\
\hline Men & $36.0 \%$ & $39.7 \%$ \\
\hline \multicolumn{3}{|c|}{ Type of higher education institution } \\
\hline College & $56.6 \%$ & $28.2 \%$ \\
\hline University & $63.2 \%$ & $71.8 \%$ \\
\hline \multicolumn{3}{|c|}{ Cycle of study } \\
\hline Bachelor's & $84.9 \%$ & $80.8 \%$ \\
\hline Master's & $45.4 \%$ & $17.3 \%$ \\
\hline Doctoral & $11.2 \%$ & $0.9 \%$ \\
\hline
\end{tabular}

Measures. Critical thinking skills were analysed in an empirical study designed to compare how much attention teachers give to the development of critical thinking skills when working with students, and how students evaluate the intensity of the attention that is given. The following skills were included for investigation: analysis, interpretation, inference, explanation, evaluation, argumentation, decision-making. The research participants completed separate online questionnaires designed for teachers and students. There were questions determining: which conception of critical thinking is prioritised, what is understanding of critical thinking, whether critical thinking is acquired or innate quality. The instrument for measuring the attitude toward the nature of critical thinking consisted of six statements that the research participants evaluated on a 5-point Likert scale. The development of critical thinking was examined by questions about the development of specific critical thinking skills, namely, how much attention the teachers gave to the development of students' critical thinking skills in the study process, and the students' evaluation of how much attention was given to the critical thinking skills in the study programmes that they were in. Each item should be evaluated on a 7-point scale from 1 (no attention at all) to 7 (particular attention). Cronbach's alpha ( $\alpha$ ) measure of internal consistency, which helps to determine whether each individual variable that makes up the scale serves the overall purpose of the scale (Aiken, 2002; Drost, 2011), was used to validate the instrument. In evaluating the statements on the manifestation and development of critical thinking, Cronbach's alpha coefficient ranged from 0.961 to 0.456 for the teacher questionnaire, and from 0.974 to 0.692 for the student questionnaire. 
Data analysis. Descriptive and inferential statistical methods were applied for data analysis, using SPSS 23. The Kolmogorov-Smirnov Z test was used to identify the normality of the distribution. The non-parametric Chi-square $(\chi 2)$ test of independence and the analysis of the variance method were used to evaluate the statistical significance of Mann-Whitney U differences between groups.

A factor analysis of the student and teacher samples was performed in order to investigate in searching which model best explained the development of critical thinking skills. Exploratory factor analysis (EFA) was used to investigate the factorial structure of the critical thinking skills in the student and teacher samples. The purpose of EFA is to describe multidimensional data of the student and teacher samples using fewer variables. EFA was conducted using Mplus 8.4 with the MLR estimator. Before proceeding to the analysis, the eligibility of the data for EFA was assessed by performing the KaiserMeyer-Olkin (KMO) test and then Bartlett's test of sphericity. In both samples, the KMO value was close to or higher than 0.70 , and Bartlett's test was significant $(p<0.001)$, supporting the factorability of the correlation matrix. The extracted factors were expected to be correlated, so an oblique rotation strategy, Geomin rotation, was used to interpret the factors (Sass \& Schmitt, 2010). Oblique rotation strategy provides for correlations among the latent constructs.

Factor eigenvalues and a set of model-data fit indicators were also used to determine the optimal number of factors (looking for solutions that had RMSEA and SRMR values lower than 0.08 and CFI values higher than 0.90 , as they indicated acceptable CFI, RMSEA and SRMR, the most likely popular measures of goodness-of-model fit). In examining the factor eigenvalues, solutions that had factors with an eigenvalue greater than 1 (Brown, 2015) were considered. In both the samples, model fit statistics supported the two-factor solution. That is, in both samples, the one-factor solution did not show a good model-data fit in terms of CFI, RMSEA, and SRMR statistics. In addition, the eigenvalue for the third factor was less than 1 , showing that a third factor may not be meaningful. The two-factor solution, however, was a good fit with the data and in both samples. The results are presented in Table 2.

\section{Table 2}

The Results of Exploratory Factor Analysis and Model Fit Indices

\begin{tabular}{|c|c|c|c|c|c|c|c|}
\hline \multirow{2}{*}{ Factor } & \multirow{2}{*}{ Eigenvalues } & \multicolumn{6}{|c|}{ Model fit indices } \\
\hline & & $\chi^{2}$ & $\mathrm{df}$ & $\mathrm{n}_{\mathrm{par}}$ & CFI & RMSEA & SRMR \\
\hline \multicolumn{8}{|c|}{ Teachers $(\mathrm{N}=152)$} \\
\hline 1 & 2.263 & 27.67 & 9 & 18 & 0.780 & 0.117 & 0.059 \\
\hline 2 & 1.101 & 5.83 & 4 & 23 & 0.978 & 0.055 & 0.021 \\
\hline 3 & 0.782 & \multicolumn{6}{|c|}{ Did not converge } \\
\hline
\end{tabular}




\begin{tabular}{lccccccc}
\hline \multicolumn{7}{c}{ Students $(\mathrm{N}=1512)$} \\
\hline 1 & 2.575 & 987.68 & 9 & 18 & 0.490 & 0.268 & 0.150 \\
2 & 1.728 & 36.41 & 4 & 23 & 0.983 & 0.073 & 0.019 \\
3 & 0.596 & 0.00 & 0 & 27 & 1.00 & 0.000 & 0.000 \\
\hline
\end{tabular}

Note. $\chi^{2}$ - Chi-square goodness of fit test; $\mathrm{df}$ - degrees of freedom; $\mathrm{n}_{\mathrm{par}}$ - the number of free parameters in the model; CFI - comparative fit index; RMSEA - root mean square error of approximation; SRMR - standardised root mean square residual.

\section{Results}

The conception of critical thinking. In order to determine which conception of critical thinking teachers and students adhere to, they were asked to choose one of the seven descriptions of critical thinking that they most related to. Over one-third (36.2\%) of the teachers and around one-quarter (24.1\%) of the students choose the description of critical thinking as the totality of a person's cognitive skills (to interpret and analyse, to explain and evaluate, and to draw conclusions and make the corrections stemming from them) and dispositions (open-mindedness and inquisitiveness, analyticity and systematicity, trust in soundness and the pursuit of truth. A small proportion of the students (7.5\%) and teachers (5.3\%) believed that critical thinking is the improvement of a person's thinking by changing habitual thinking patterns. When comparing critical thinking understanding of teachers and students, one statistically significant difference was found: the teachers were more likely than the students to respond that critical thinking is the totality of a person's cognitive skills and dispositions $\left(\chi^{2}=15.560 ; \mathrm{df}=6 ; \mathrm{p}<0.05\right)$.

Critical thinking understanding. The teachers essentially adhered to dynamism, i.e., that critical thinking is a changing personal skill. The majority of the teachers agreed or strongly agreed with the following statements: that critical thinking can be developed (92.8\%), that there are various ways to demonstrate critical thinking (88.1\%) and that critical thinking is possible in every situation (81.0\%). Teachers' opinions differed more regarding the statement that a person can think critically if he or she wants and tries to, i.e. $71.1 \%$ of the teachers agreed, while slightly more than one-fifth (21.7\%) neither agreed nor disagreed and $7.3 \%$ did not agree. With statements about critical thinking as a static, unchanging personal characteristic, teachers largely disagreed. That a person's ability to think critically is unchanging did not agree $72.4 \%$ and that critical thinking only occurs when criticising did not agree $84.2 \%$ of the teachers. Generally, the teachers understand critical thinking as a dynamic, developed, and changing process that every person needs in different situations.

The opinion of students is very close to that of the teachers, but there are several differences. $76.0 \%$ of the students were inclined to agree with the statement that critical thinking can be developed, and more than two-thirds of the students were inclined to 
agree with the statement that there are various ways to demonstrate critical thinking (70.8\%), critical thinking is possible in every situation (69.1\%), and a person can think critically if he or she wants and tries to (68\%). Thus, the students basically recognised the role and effort of the person in the manifestation of critical thinking. However, compared to the teachers, the students were more scattered when responding to the statements illustrating the one-sided, static nature of critical thinking. More than a third of the students tended to agree that critical thinking only occurs when criticising (38.8\%), and that a person's ability to think critically is unchanging (38.3\%).

A Mann-Whitney test was performed in order to compare teachers' and students' understanding of critical thinking (Table 3).

\section{Table 3}

Teachers' and Students' Understanding of Critical Thinking; the Mann-Whitney Criterion Denotes the Rank

\begin{tabular}{lccc}
\hline & $\begin{array}{c}\text { Mean rank, } \\
\text { teachers responses }\end{array}$ & $\begin{array}{c}\text { Mean rank, } \\
\text { students responses }\end{array}$ & $\begin{array}{c}\text { Mann-Whitney } \\
\text { U }\end{array}$ \\
\hline $\begin{array}{l}\text { A person's ability to think } \\
\text { critically is unchanging }\end{array}$ & 997.2 & 815.94 & $68728.000^{* * *}$ \\
$\begin{array}{l}\text { A person can think critically if } \\
\text { he or she wants and tries to } \\
\begin{array}{l}\text { Critical thinking is possible in } \\
\text { every situation }\end{array}\end{array}$ & 873.44 & 828.38 & 108688.500 \\
$\begin{array}{l}\text { There are various ways to } \\
\text { demonstrate critical thinking } \\
\begin{array}{l}\text { Critical thinking only occurs } \\
\text { when criticising }\end{array}\end{array}$ & 1136.34 & 801.96 & $95905.000^{* * *}$ \\
$\begin{array}{l}\text { Critical thinking can be devel- } \\
\text { oped }\end{array}$ & 980.96 & 794.34 & $92345.500^{* * *}$ \\
\hline
\end{tabular}

Note. Statistically significant parameter when: ${ }^{*} \mathrm{p}<0.05 ;{ }^{* *} \mathrm{p}<0.01 ;{ }^{* * *} \mathrm{p}<0.001$

Data analysis revealed that teachers' and students' understanding of critical thinking differed. A highly significant difference (Table 3 ) was identified in that the teachers agree more than the students that there are various ways to demonstrate critical thinking and that critical thinking is possible in every situation $(\mathrm{U}=92345.500 ; \mathrm{p}<0.001)$. Also, a significant difference was found in that the teachers were more likely than the students to agree that a person's ability to think critically is unchanging $(U=68728.000 ; \mathrm{p}<0.001)$.

Development of critical thinking skills. The study revealed that, in developing students' critical thinking skills, the teachers paid attention to working with all listed critical thinking skills. The teachers allocated particular attention to developing the constituents of the inference $(M=5.95)$, interpretation $(M=5.93)$ and argumentation $(M=5.92)$ skill groups. 
The teachers gave a bit less attention to developing the abilities in the other groups, i.e., analysis $(M=5.85)$, evaluation ( $M=5.77)$, and explanation $(M=5.76)$. The least attention was given to developing decision-making $(M=5.52)$ and self-regulation $(M=5.26)$ skills.

According to the students' evaluations of how much attention is paid to the development of critical thinking skills in the study programme that they were in, the most attention was given to developing argumentation $(M=5.33)$, inference $(M=5.25)$, and decision-making $(M=5.22)$ skills. A bit less attention was given to self-regulation $(M=5.19)$ and explanation $(M=5.17)$ skills, and the least attention was given to interpretation $(M=5.10)$, analysis $(M=5.06)$, and evaluation $(M=5.05)$ skills.

The study sought to compare how much teachers focus on developing critical thinking skills when working and interacting with students, and according to the students, how much attention is paid to the development of these skills in their study programme (Table 4).

Table 4

Comparison of an Attention Given to the Development of Critical Thinking Skills

\begin{tabular}{lccc}
\hline & $\begin{array}{c}\text { Mean rank, } \\
\text { teacher responses }\end{array}$ & $\begin{array}{c}\text { Mean rank, } \\
\text { student responses }\end{array}$ & $\begin{array}{c}\text { Mann-Whitney } \\
\text { U }\end{array}$ \\
\hline Self-regulation & 832.41 & 832.51 & 114896.500 \\
Decision-making & 956.83 & 823.02 & $100574.000^{*}$ \\
Explanation & 1029.92 & 812.65 & $84903.500^{* * *}$ \\
Argumentation & 1030.34 & 812.61 & $84841.000^{* * *}$ \\
Inference & 1059.23 & 809.71 & $80448.500^{* * *}$ \\
Evaluation & 1087.65 & 808.86 & $79168.500^{* * *}$ \\
Analysis & 1108.32 & 804.77 & $72987.500^{* * *}$ \\
Interpretation & 1110.44 & 804.56 & $72664.500^{* * *}$ \\
\hline
\end{tabular}

Note. Statistically significant parameter when: ${ }^{*} \mathrm{p}<0.05 ;{ }^{* *} \mathrm{p}<0.01 ;{ }^{* * *} \mathrm{p}<0.001$

Statistically significant differences were found in the following cases: the teachers agreed more than the students that, in the study process, attention was given to the critical thinking skills of interpretation $(\mathrm{U}=72664.500 ; \mathrm{p}<0.001)$, analysis $(\mathrm{U}=72987.500$; $\mathrm{p}<0.001)$, evaluation $(\mathrm{U}=79168.500 ; \mathrm{p}<0.001)$, inference $(\mathrm{U}=80448.500 ; \mathrm{p}<0.001)$, argumentation $(\mathrm{U}=84841.000 ; \mathrm{p}<0.001)$ and explanation $(\mathrm{U}=84903.500 ; \mathrm{p}<0.001)$. Furthermore, a small but significant difference was found in decision-making skills. Meanwhile, responses of the teachers and the students coincided concerning the attention given to developing self-regulation skills.

Factor structure of critical thinking understanding scale. A factor analysis of the student and teacher samples was performed in order to investigate which model best explains the development of critical thinking skills. Factor loading is a correlation coefficient between each variable and each factor in factor analysis. While the factor loadings had some 
similarities across the student and teacher samples, there were also some notable differences. In particular, in both samples, Items 3 and 4 had clear and strong associations with the first factor, while Items 2, 5, and 6 had clear associations with the second factor. However, the first item on the scale had different associations with two factors across two samples. In the teacher sample, the first item loaded negatively on the first factor, while in the student sample, it loaded positively on the second factor. This result suggested that the factor structure of the scale was somewhat different across the two samples. It also suggested that the items should be grouped differently for the teachers and the students. Despite this difference, the meaning of the factors across the two samples was fairly similar. According to the essence of the items, it labelled the first as 'rigidity' and the second as 'elasticity'. The internal consistency belonging to these two factors was also sufficient. The Cronbach's alpha coefficient was 0.60 for the rigidity factor in the teacher sample and 0.86 in the student sample, while the alpha coefficient for the elasticity factor was 0.58 in the teacher sample and 0.80 in the student sample. Standardised loadings from the two-factor solution are presented in Table 5.

\section{Table 5}

Standardised Factor Loadings Obtained from EFA of Critical Thinking Understanding Scale in the Teacher and Student Samples

\begin{tabular}{lcccc}
\hline \multirow{2}{*}{ Item } & \multicolumn{2}{c}{ Teacher sample } & \multicolumn{2}{c}{ Student sample } \\
\cline { 2 - 5 } & $\lambda_{1}$ & $\lambda_{2}$ & $\lambda_{1}$ & $\lambda_{2}$ \\
\hline Critical thinking can be developed & -0.40 & 0.17 & -0.15 & 0.78 \\
$\begin{array}{l}\text { A person can think critically if he or she wants and } \\
\text { tries to }\end{array}$ & 0.01 & 0.67 & -0.01 & 0.71 \\
$\begin{array}{l}\text { A person's ability to think critically is unchanging } \\
\text { Critical thinking only occurs when criticising }\end{array}$ & 0.80 & 0.00 & 0.84 & 0.01 \\
$\begin{array}{l}\text { There are various ways to demonstrate critical } \\
\text { thinking }\end{array}$ & -0.17 & 0.37 & 0.10 & 0.69 \\
Critical thinking is possible in every situation & -0.01 & 0.58 & 0.13 & 0.64 \\
\hline
\end{tabular}

Note. $\lambda_{1}$ - standardised loading on the first factor; $\lambda_{2}$ - standardised loading on the second factor. Factor loading is a correlation coefficient between each variable and each factor in a factor analysis.

The teachers who held the understanding that critical thinking is static had a negative assessment of the possibilities for developing critical thinking $(\lambda=-0,40)$, and very strongly supported the positions that a person's ability to think critically is unchanging $(\lambda=0.80)$ and that critical thinking only occurs when criticising $(\lambda=0.53)$. Meanwhile, the teachers who held the understanding that critical thinking can be learned agreed that a person can think critically if he or she wants and tries to $(\lambda=0.67)$, that critical thinking is possible in every situation $(\lambda=0.58)$, and that there are various ways to demonstrate critical thinking $(\lambda=0.37)$. The situation in the student sample was very similar. Those, whose understanding 
was that critical thinking is innate strongly agreed that a person's ability to think critically is unchanging $(\lambda=0.84)$ and that critical thinking only occurs when criticising $(\lambda=0.90)$. The students, whose understanding was that critical thinking can be acquired, strongly supported that critical thinking can be developed $(\lambda=0.78)$, a person can think critically if he or she wants and tries to $(\lambda=0.71)$, there are various ways to demonstrate critical thinking $(\lambda=0.69)$, and critical thinking is possible in every situation $(\lambda=0.64)$.

Interaction between the rigidity and elasticity of the conception of critical thinking and the development of critical thinking skills in the teacher sample. A path model was built and tested to examine the interaction between understanding of critical thinking and the critical thinking skills that are developed the most. In the path model, the factor scores for each of these dimensions were used as outcome variables, and the item-total scores of the rigidity and elasticity of critical thinking were used as predictors of outcome variables. The standardised slope parameter estimates from the path model linking understanding of critical thinking with the critical thinking skills that are developed the most are presented in Table 6.

Table 6

Standardised Slope Parameter Estimates From the Path Model Linking Understanding of Critical Thinking With the Critical Thinking Skills That are Developed the Most $(N=152)$

\begin{tabular}{|c|c|c|c|c|c|c|c|c|c|}
\hline \multirow[b]{2}{*}{$\begin{array}{l}\text { Predictor varia- } \\
\text { bles: Understan- } \\
\text { ding the nature } \\
\text { of critical thin- } \\
\text { king }\end{array}$} & \multicolumn{9}{|c|}{ Outcome variables: Critical thinking skills } \\
\hline & 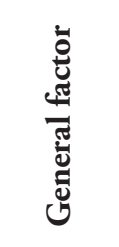 & 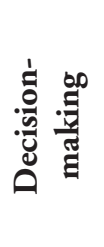 & 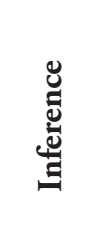 & 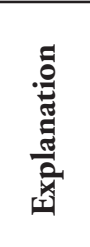 & $\begin{array}{l}\frac{n}{0} \\
\frac{0}{n} \\
\frac{\pi}{4}\end{array}$ & 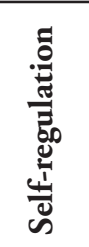 & 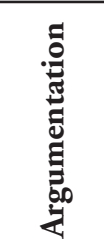 & 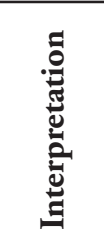 & 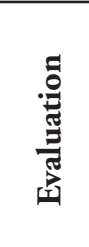 \\
\hline $\begin{array}{l}\text { Rigidity of critical } \\
\text { thinking }\end{array}$ & $-0.18^{*}$ & 0.01 & 0.07 & 0.06 & -0.07 & 0.09 & 0.01 & $-0.19^{*}$ & -0.12 \\
\hline $\begin{array}{l}\text { Elasticity of criti- } \\
\text { cal thinking }\end{array}$ & $0.23^{* *}$ & 0.14 & -0.10 & 0.02 & 0.11 & 0.08 & 0.03 & -0.06 & -0.07 \\
\hline $\mathrm{R}^{2}$ & 0.07 & 0.02 & $<0.01$ & 0.01 & 0.02 & 0.02 & $<0.01$ & 0.04 & 0.02 \\
\hline
\end{tabular}

Note. Parameter is statistically significant when ${ }^{*} \mathrm{p}<0.05$ and ${ }^{* *} \mathrm{p}<0.01$.

$\mathrm{R}^{2}$ - the coefficient of determination, which indicates the proportionate amount of variation in the outcome variable explained by predictor variables.

In general, there was one notable pattern of interaction. The rigidity factor negatively predicted, while the elasticity factor positively predicted the general factor of the critical thinking skills that are developed. This finding shows that teachers who understand critical thinking skills as being very rigid and inflexible tend to put less effort into developing all of the skills related to critical thinking, while those who understand critical 
thinking skills as being flexible and teachable tend to put more effort into developing all the skills related to critical thinking. Only one association emerged with the specific factor - the rigidity of critical thinking negatively predicted the teaching of interpretation skills. It shows that teachers who understand of critical thinking skills as being very rigid tended to put less effort into developing interpretation skills when working and interacting with students.

\section{Discussion and Conclusions}

The research data revealed that the teachers and the students understand critical thinking as it is defined by Facione (1990), i.e., that critical thinking is the totality of a person's cognitive skills (to interpret and analyse, to explain and evaluate, and to draw conclusions and make the corrections stemming from them). The least acceptable understanding of critical thinking was associated with the conception of critical thinking as improvement, as defined by Halpern (1998) and Paul and Elder (2001). The concepts of critical thinking put forward by other authors, such as Siegel (1988), Beyer (1987), Barnett (1997), and Ennis (1987), are less known and less used by the research participants. The results also show that critical thinking manifests itself as the ability to make decisions based on real-life problems. This is not unique to this study, and is also confirmed by other studies (Liu et al., 2016; Eagan et al., 2014), which argue that critical thinking is one of the most important learning outcomes expected of graduates and is reinforced by the observations of Giancarlo and Facione (2001) that critical thinking is an independent and well-organised cognitive process leading to high-quality conclusions and decisions.

The teachers understood critical thinking as a dynamic, developing, and changing skill that every person needs in different situations. The students understood critical thinking as being developed and demonstrated in each situation and in a variety of ways. Critical thinking was seen as a process that depends on a person's skills, dispositions, values, and beliefs. According to the research participants, anyone can think critically as long as they want to and make an effort to do so. This dynamism is related to the individual's capacity, when an active, reflexive actor can influence his or her own decisions and create and re-create a social reality accordingly, and use available resources to transform the social structure. This finding responds to the idea of the interaction between the individual and the social structure (Giddens, 1986). Teachers and students understand critical thinking as a changing process that helps a person to demonstrate critical thinking skills in different ways, depending on the situation, and associate critical thinking with the efforts of each individual. In general, the research participants do not think that critical thinking only occurs when criticising, although at least a third of the students take the opposite understanding. Other studies, such as the one conducted by Hyytinen et al. (2014), also revealed that students' critical thinking can be characterised 
by both flexibility and rigidity, which in turn allows students to adapt their thinking or behave according to established patterns.

The results revealed that the process of developing critical thinking is not uniform. It is influenced by the teachers or, more specifically, their understanding of what critical thinking is, their position toward the possibility of developing this thinking, and finally, the specific attention they give to developing critical thinking skills. The complexity of developing critical thinking was also noted by Abrami et al. (2015), who argued that developing critical thinking is a complex and manifold process. The teachers indicated that, in the study process, they developed all of the critical thinking skills presented, but to varying degrees. They gave slightly more attention to the development of argumentation, interpretation, and inference skills, and less to skills related to assessing or presenting context, different attitudes or perspectives to others. These results raise new questions about how deep of an understanding the teachers have about the essence of critical thinking.

The importance of teachers understanding is also illustrated by other studies (Grant \& Smith, 2018; Zhang et al., 2020) which confirm that the understanding of critical thinking and the frame of mind of teachers are related to how they develop critical thinking, what work methods they use, what tasks they give to students, and what criteria they apply for assessing. In the presented research the model was designed to show the internal structure of the understanding of critical thinking. It showed that the development of critical thinking is essentially influenced by the understanding of the teacher regarding whether critical thinking is an innate or an acquired quality. When working and interacting with students, teachers who understood critical thinking as an innate quality put less effort into developing all of the skills related to critical thinking, and vice versa - i.e., teachers who understood critical thinking as a certain skill that can be learned tended to put more effort into developing all of the skills related to critical thinking.

As Mahdi et al. (2020) argue, developing critical thinking skills also improves studentlearning outcomes. According to the students, attention was given in study programmes to the development of all critical thinking skills, but a bit more attention was given to developing argumentation, inference, and decision-making skills. It should be noted that the students felt that teachers gave the least attention to developing analysis, interpretive and evaluation skills.

Teachers who understood critical thinking skills as being very rigid and inflexible tend to put less effort into developing all of the skills related to critical thinking, while those who understood critical thinking skills as being flexible and teachable tend to put more effort into developing all the skills related to critical thinking. The rigidity of critical thinking negatively predicted one specific critical thinking skill - the teaching of interpretation skills. The research findings can be seen as contributing to a better understanding of how individual understandings of critical thinking and its teaching and learning interact. 
Funding: This article was supported by the European Social Fund (project No 09.3.3-LMT-K-712-01-0068) under a grant agreement with the Research Council of Lithuania (LMTLT).

\section{References}

Abrami, P., Bernard, R., Borokhovski, E., Waddington, D., Wade, C., \& Persson, T. (2015). Strategies for teaching students to think critically: A meta-analysis. Review of Educational Research, 85(2), 275-314. https://doi.org/10.3102/0034654314551063

Aiken, L. R. (2002). Psychological testing and assessment (11th ed.). Allyn and Bacon.

Arth, Z. W., Griffin, D. J., \& Earnest, W. J. (2019). Professors' perspectives on truth-seeking and new literacy. Journal of Media Literacy Education, 11(3), 61-72. https://doi.org/10.23860/ JMLE-2019-11-3-6

Barnett, R. (1997). Higher Education: A Critical Business. Buckingham: The Society for Research into Higher Education and Open University Press.

Beyer, B. K. (1987). Practical strategies for the teaching of thinking. Allyn and Bacon.

Borg, S. (2003). Teacher cognition in language teaching: A review of research on what language teachers think, know, believe and do. Language Teaching, 36(2), 81-109. https://doi.org/10.1017/ $\underline{\text { S0261444803001903 }}$

Brown, T. A. (2015). Confirmatory factor analysis for applied research (2nd ed.). The Guilford Press,

Cohen, M. (1993). Making critical thinking a classroom reality. PS: Political Science \& Politics, 26(2), 241-244. https://doi.org/10.2307/419838

Crenshaw, P., Hale E., \& Harper, S. L. (2011). Producing intellectual labor in the classroom: The utilization of a critical thinking model to help students take command of their thinking. Journal of College Teaching \& Learning, 8(7), 13-26. https://doi.org/10.19030/tlc.v8i7.4848

Dehghayedi, M., \& Bagheri, M. S. (2018). EFL teachers' learning and teaching beliefs: Does critical thinking make a difference? International Journal of Instruction, 11(4), 223-240. https://doi. org/10.12973/iji.2018.11415a

Drost, E. A. (2011). Validity and reliability in social science research. Education Research and perspectives, 38(1), 105-123.

Dwyer, C. P., Hogan, M. J., \& Stewart, I. (2012). An evaluation of argument mapping as a method ofenhancing critical thinking performance in e-learning environments. Metacognition and Learning, 7(3), 219-244. https://doi.org/10.1007/s11409-012-9092-1

Eagan, M., Stolzenberg, E., Berdan Lozano, J., Aragon, M., Suchard, M., \& Hurtado, S. (2014). Undergraduate teaching faculty: The 2013-2014 HERI faculty survey. UCLA, Los Angeles: Higher Education Research Institute. https://heri.ucla.edu/monographs/HERI-FAC2014monograph.pdf

Edwards, L. C. (2017). The craft of infusing critical thinking skills: a mixed-method research on implementation and student outcome. Journal on Centers for Teaching \& Learning, 9, 47-72. https://openjournal.lib.miamioh.edu/index.php/jctl/article/view/189/97 
Ennis, R. H. (1987). A taxonomy of critical thinking dispositions and abilities. In J. B. Baron \& R. J. Sternberg (Eds.), Teaching thinking skills: Theory and practice (pp. 9-26). W H Freeman/ Times Books/ Henry Holt \& Co..

Evens, M., Vergurgh, A., \& Elen, J. (2014). The development of critical thinking in professional and academic bachelor programmes. Higher education studies, 4(2), 42-51. https://doi. org/10.5539/hes.v4n2p42

Facione, N. C., \& Facione, P. A. (1996). Externalizing the critical thinking in knowledge development andcritical judgment. Nursing Outlook, 44(3), 129-136. https://doi.org/10.1016/ S0029-6554(06)80005-9

Facione, P. A. (1990). Critical thinking: A statement of expert consensus for purposes of educational assessment and instruction. Research findings and recommendations. Fullerton: California State University.

Fitriani, S. S., Yusuf, Y. Q., \& Zumara, A. (2021). The use of cognitive domain in questions: The perception of students and lecturers of public universities in aceh. Journal of Language and Linguistic Studies, 17, 122-138. https://doi.org/10.17263/jlls.903359

Ghanizadeh, A. (2017). The interplay between reflective thinking, critical thinking, selfmonitoring, and academic achievement in higher education. Higher Education, 74(1), 101-114. https://doi.org/10.1007/s10734-016-0031-y

Giancarlo, C. A., \& Facione, P. A. (2001). A look across four years at the disposition toward critical thinking among undergraduate students. The Journal of General Education, 50(1), 29-55. https://www.jstor.org/stable/27797861

Giddens, A. (1986). Action, subjectivity, and the constitution of meaning. Social Research, 53(3), 529-545.

Gillespie, L., \& McBain, S. (2014). A critical challenge: Developing student's critical abilities. New Zealand Physical Educator, 47(2), 5-9. https://hdl.handle.net/10289/9436

Grant, M., \& Smith, M. (2018). Quantifying assessment of undergraduate critical thinking. Journal of College Teaching \& Learning, 15(1), 27-38. https://doi.org/10.19030/tlc.v15i1.10199

Halpern, D. F. (1998). Teaching critical thinking for transfer across domains. American Psychologist, 53(4), 449-455. https://doi.org/10.1037/0003-066X.53.4.449

Hyytinen, H., Holma, K., Toom, A., Shavelson, R. J., \& Lindblom-Ylänne, S. (2014). The complex relationship between students' critical thinking and epistemological beliefs in the context of problem solving. Frontline Learning Research, 2(5), 1-25. https://doi.org/10.14786/flr.v2i4.124

Kozikoglu, I. (2019). Investigating critical thinking in prospective teachers: metacognitive skills, problem solving skills and academic self-efficacy. Journal of Social Studies Education Research, 10(2), 111-130. https://eric.ed.gov/?id=EJ1220699

Ku, K. Y. L. (2009). Assessing students' critical thinking performance: Urging for measurements using multi-response format. Thinking Skills and Creativity, 4, 70-76. https://doi.org/10.1016/j. tsc.2009.02.001 
Liu, O. L., Mao, L., Frankel, L., \& Xu, J. (2016). Assessing critical thinking in higher education: the HEIghten $^{\text {tw }}$ approach and preliminary validity evidence. Assessment \& Evaluation in Higher Education, 41(5), 677-694. https://doi.org/10.1080/02602938.2016.1168358

Mahdi, O. R., Nassar, I. A., \& Almuslamani, H. A. I. (2020). The role of using case studies method in improving students' critical thinking skills in higher education. International Journal of Higher Education, 9(2), 297-308. https://doi.org/10.5430/ijhe.v9n2p297

Niu, L., Behar-Horenstein, L. S., \& Garvan, C. W. (2013). Do instructional interventions influence college students' critical thinking skills? A meta-analysis. Educational Research Review, 9, 114-128. https://doi.org/10.1016/j.edurev.2012.12.002

Norris, M. E. (2016). Fostering student credibility through sustainable engagement initiatives: An application of the Service, Operative, and Lecture-Learning (SOLL) Model. Journal of Service-Learning in Higher Education, 5(1). https://eric.ed.gov/?id=EJ1186307

Özelçi, S. Y., \& Çaliskan, G. (2019). What is critical thinking? A longitudinal study with teacher candidates. International Journal of Evaluation and Research in Education, 8(3), 495-509. http://doi.org/10.11591/ijere.v8i3.20254

Paul, R., \& Elder, L. (2001). Critical thinking: Tools for taking charge of your learning and your life. Upper Saddle River: Prentice Hall.

Pearman, C., Bowles, F., \& Polka, W. (2021). Teacher educator perceptions of characteristics of self-efficacy. Critical Questions in Education, 12(1), 81-99. https://eric.ed.gov/?id=EJ1287249

Penningroth, S. L., Despain, L. H., \& Gray, M. J. (2007). A course designed to improve psychological critical thinking. Teaching of Psychology, 34(3), 153-157. https://doi. org/10.1080/00986280701498509

Puig, B., Blanco-Anaya, P., Bargiela, I. M., \& Crujeiras-Pérez, B. (2019). A systematic review on critical thinking intervention studies in higher education across professional fields. Studies in Higher Education, 44(5), 860-869. https://doi.org/10.1080/03075079.2019.1586333

Sass, D. A., \& Schmitt, T. A. (2010). A comparative investigation of rotation criteria within exploratory factor analysis. Multivariate Behavioral Research, 45(1), 73-103. https://oi. org/10.1080/00273170903504810

Siegel, H. (1988). Educating reason: rationality, critical thinking and education. Routledge.

Smith, J. W., \& Stitts, D. K. (2013). Using action learning and critical thinking tools to make changes in higher education. Contemporary Issues in Education Research, 6(1), 74-84. https:// doi.org/10.19030/cier.v6i1.7605

Tang, K. N. (2019). Beyond employability: Embedding soft skills in higher education. Turkish Online Journal of Educational Technology - TOJET, 18(2), 1-9. https://files.eric.ed.gov/fulltext/ EJ1211098.pdf

Tiruneh, D. T., De Cock, M., \& Elen, J. (2018). Designing learning environments for critical thinking: Examining effective instructional approaches. International Journal of Science \& Mathematics Education, 16(6), 1065-1089. https://doi.org/10.1007/s10763-017-9829-z

Torff, B. (2005). Developmental changes in teachers' beliefs about critical-thinking activities. Journal of Educational Psychology, 97(1), 13-22. https://doi.org/10.1037/0022-0663.97.1.13 
Toshpulatova, D., \& Kinjemuratova, A. (2020). Teacher perceptions on developing students' critical thinking skills in academic english module. International Journal of Psycho-Educational Sciences, 9(1), 48-60. https://eric.ed.gov/?id=EJ1250659

Tsui, L. (2008). Cultivating critical thinking: Insights from an elite liberal arts college. JGE: The Journal of General Education, 56(3-4), 200-227. https://doi.org/10.1353/ige.0.0001

Veliz, L., \& Veliz-Campos, M. (2019). An interrogation of the role of critical thinking in English language pedagogy in Chile. Teaching in Higher Education, 24(1), 47-62. https://doi.org/10. $\underline{1080 / 13562517.2018 .1456424}$

Wilson, K. (2016). Critical reading, critical thinking: Delicate scaffolding in English for academic purposes (EAP). Thinking Skills and Creativity, 22, 256-265. https://doi.org/10.1016/j. $\underline{\text { tsc. } 2016.10 .002}$

Wright, G. (2011). Student-centered learning in higher education. International Journal of Teaching and Learning in Higher Education, 23(3), 92-97. https://eric.ed.gov/?id=EJ938583

Zhang, H., Yuan, R., \& He, X. (2020). Investigating university EFL teachers' perceptions of critical thinking and its teaching: Voices from China. Asia-Pacific Education Researcher, 29(5), 483-493. https://doi.org/10.1007/s40299-020-00500-6

\title{
Kritinio mąstymo supratimo ir kritinio mąstymo igūdžiu mokymo(si) sąveika
}

\author{
Valdonė Indrašiene் $\dot{1}^{1}$, Violeta Jegelevičiené2 ${ }^{2}$ Odeta Merfeldaité ${ }^{3}$, Daiva Penkauskiené ${ }^{4}$,

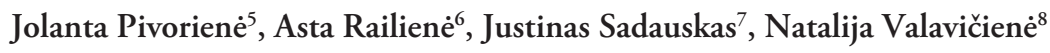

1 Mykolo Romerio universitetas, Edukologijos ir socialinio darbo institutas, Ateities g. 20, 08303 Vilnius, Lietuva, v.indrasiene@mruni.eu

2 Mykolo Romerio universitetas, Edukologijos ir socialinio darbo institutas, Ateities g. 20, 08303 Vilnius, Lietuva, violeta.suboc@mruni.eu

3 Mykolo Romerio universitetas, Edukologijos ir socialinio darbo institutas, Ateities g. 20, 08303 Vilnius, Lietuva, o.merfeldaite@mruni.eu

4 Mykolo Romerio universitetas, Edukologijos ir socialinio darbo institutas, Ateities g. 20, 08303 Vilnius, Lietuva, daiva. penkauskiene@mruni.eu

5 Mykolo Romerio universitetas, Edukologijos ir socialinio darbo institutas, Ateities g. 20, 08303 Vilnius, Lietuva, jolantapiv@mruni.eu

6 Mykolo Romerio universitetas, Edukologijos ir socialinio darbo institutas, Ateities g. 20, 08303 Vilnius, Lietuva, asta. railiene@mruni.eu

7 Mykolo Romerio universitetas, Edukologijos ir socialinio darbo institutas, Ateities g. 20, 08303 Vilnius, Lietuva, justas_sad@mruni.eu

8 Mykolo Romerio universitetas, Edukologijos ir socialinio darbo institutas, Ateities g. 20, 08303 Vilnius, Lietuva, natalijav@mruni.eu

\section{Santrauka}

Sparčiai besikeičiančiame, informacijos valdomame pasaulyje kritinis mąstymas laikomas vienu iš aukštojo mokslo tikslų. Kritinio mąstymo ugdymas įvardijamas kaip sąmoninga ir 
tikslinga mokymo ir mokymosi veikla: dėstytojai laikomi aktyviais veikejjais, kurių supratimas apie kritinị mąstymą daro ịtaką jų darbui ir sąveikai su studentais ugdant kritinị mąstymą. Šio straipsnio tikslas - pristatyti supratimo apie kritinị mąstymą ir kritinio mąstymo igūdžių mokymo ir mokymosi sąveiką Lietuvos aukštosiose mokyklose. Atliktas reprezentatyvus kiekybinis tyrimas, internetinejje apklausoje dalyvavo 152 dèstytojai ir 1512 studentų. Tyrimo duomenys atskleidè, kad dèstytojai ir studentai laikèsi nuomonès, jog kritinis mąstymas yra asmens pažintinių gebejjimų visuma. Kritinis mąstymas vertinamas kaip procesas, kuris priklauso nuo asmens igūdžių, polinkių, vertybių ir įsitikinimų. Faktorinė analizė atskleidè du veiksnius kritinio mąstymo sampratos nelankstumą ir elastingumą, - turinčius įtakos kritinio mąstymo igūdžių mokymui ir mokymuisi. Pirmasis veiksnys apima supratimą, kad kritinis mąstymas yra igyta savybe், kurią galima ugdyti, antrasis - kad kritinis mąstymas yra igimta asmens savybe், todèl statiška. Šie veiksniai sąveikauja su pastangomis mokyti ar mokytis kritinio mąstymo.

Esminiai žodžiai: kritinis mąstymas, aukštasis mokslas, kritinio mąstymo ịgūdžiai, mokymas, mokymasis.

Gauta 20211020 / Received 20102021

Priimta 20211213 / Accepted 13122021 